\title{
TRAINING OF E-COMMERCE IMPLEMENTATION AS ONLINE MEDIA SELLING TO GROUP OF BATIK “ARIMBI" CRAFTSMAN AT KEDUNGKAMAL VILLAGE, GRABAG, PURWOREJO.
}

\author{
Slamet Mudjijah ${ }^{1 *}$, Astrid Hakim ${ }^{1}$ \\ ${ }^{1}$ Budi Luhur University \\ *slamet.mudjijah@budiluhur.ac.id,
}

\begin{abstract}
KedungKamal Village at GrabagPurworejo become one of reliable object to create ecotourism for local government. Local government of Purworejo develop location for Batik crafts based on local sources. One of the obstacle had been experienced business is not familiar. The community development as an e-commerce training as media of marketing online is expected able to win the business and sale product. As a whole become a local potency has owned opportunity to elevate the welfare especially local people. The activity of training as a online marketing media is expected giving effect to buy and sale of efficient marketing by using e-commerce will show the ease on transaction, reduce cost and accelerate transaction process. This activity is expected to increase the respectfulness of batik craft activity by local people particularly as one of the icon in Purworejo.
\end{abstract}

Keywords : Batik crafts,e-commerce, marketing, media.

\section{INTRODUCTION}

\section{Background}

Businiess competition flows rapidly on technology information era. It can seen from the year to year the impact of people's behave from conventional life style to modern sophtisticated life style. Nowadays, the information's can be gained limitless. People able to access the recent news through online or offline. People tried to shift the way of living including shopping behavior. They tend used technology by using internet for searching various information. As well as the way how they trade. Modern people like to be simpler and easier. This is occurs due to the activities of modern people is increasingly mobile as well the competitive advantage.

The usage of e-commerce as one tools of marketing digital. Internet is playing an important role to run this type of business. The level of e-commerce usage raises significantly among the businessman because the efficiency and more effectively. Most the consumer really enjoy to shop with this method. The benefits surely are saving time and money for both seller and buyer. E-commerce bring become breakthrough on trading method. This method more likely from both sides. The transaction has increased significantly at the last few years. Most of consumer stays in metropolitan or big cities. They have to deal with traffic and high cost of transportation. For trader, it can save the promotion cost and shop rent cost.

\section{Problem}

The house wives at Kedung Kamal Village majority works dominantly for families. However, their husband works at paddies field. While the wives helped them at the field. On the other hand at the spare time house wives involve at Batik crafts avtivitiy in order to enhance their income. But, they are facing with several problems:

1. How to enlarge the lack of marketing chanel to introduce Batik Arimbi to widely buyer?

2. How to give the house wife from Batik Arimbi's crafts a training about how to market the products using e-commerce?

\section{Extensive Market}


To elevate the potential of local Batik Arimbi at Kedung Kamal Purworejo Cental Java. It is necessary to change from conventional marketing into digital marketing. The output is despite it can raise the income of craftswomen marketing digital able to introduce Batik Arimbi product as local product from Purworejo to people widely outside Purworejo and Central Java. The pupose of these activities are to change people mindset in the term of Marketing conventional to Marketing digital. The activities to support it are as below

1. Training about how to market batik Arimbi by online.

2. Training about joining Batik Arimbi using E-commerce as their market place.

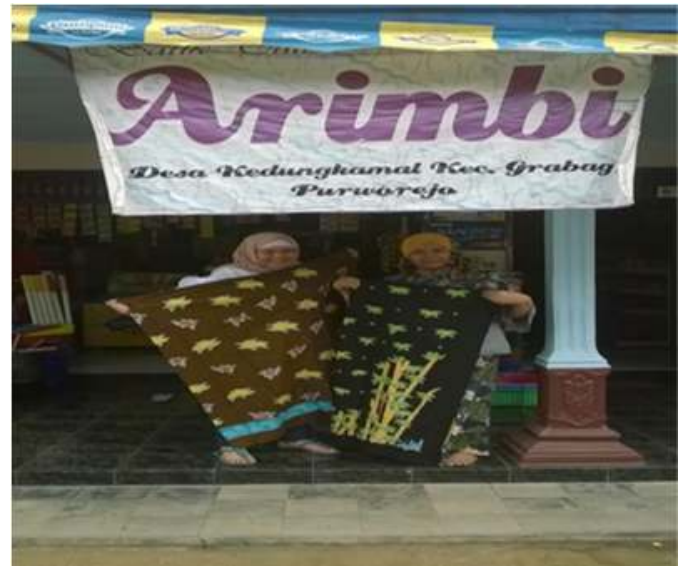

Figure 1. Traditional Batik Shop

\section{METHOD}

\section{Time and Place of Service}

Community of Batik Arimbi's craftswomen, Resident of head of Batik Arimbi's organizer at Kedung Kamal Village.The activity is carried out from April2017 to August 2017. Conducted for 5 months.Mentoring is done every one month in Kedung Kamal Village. The assistance schedule was adjusted to the capacity of the house wives joining in Batik Arimbi's craft. The productive moment at $10 \mathrm{am}-13.00 \mathrm{pm}$. The time scheduled by adjusting the spare time of the house wives.

\section{Empowerment methods and design}

The plan of activities in problem solving partners is the twoconcept, among others

1. Social Power

Invite the community to the educational process through the following approach:

a. Coordination with Batik Arimbi's organizer community leaders (RT / RW)

b. Coordination with KSM (self-help groups)

c. Activity socialization to house wives in Batik Arimbi craft

d. Educational process by giving training.

2. Marketing Power

a. Introducing online marketing and e-commerce as marketing channel.

b. Shifting from conventional marketing to digital marketing.

c. Using several renowned e-commerce as their market place.

3. Economic Power

a. Raise the gross domestic income of Purworejo citizen generally and Batik Arimbi's craftswomen.

b. Lower the marketing cost due to unnecessary promotion cost and providing real store for displaying Batik.

4. Partner Participation

During the implementation of activities, Partners participate in the implementation of the program, from the beginning until the end.In the early stages of program implementation licensing, partners participate in: 
- Providing information about the problems faced by partners especially dealing with marketing.

- Permitting Universitas Budi Luhur team from Faculty Economics and Business to conduct field studies at partner area.

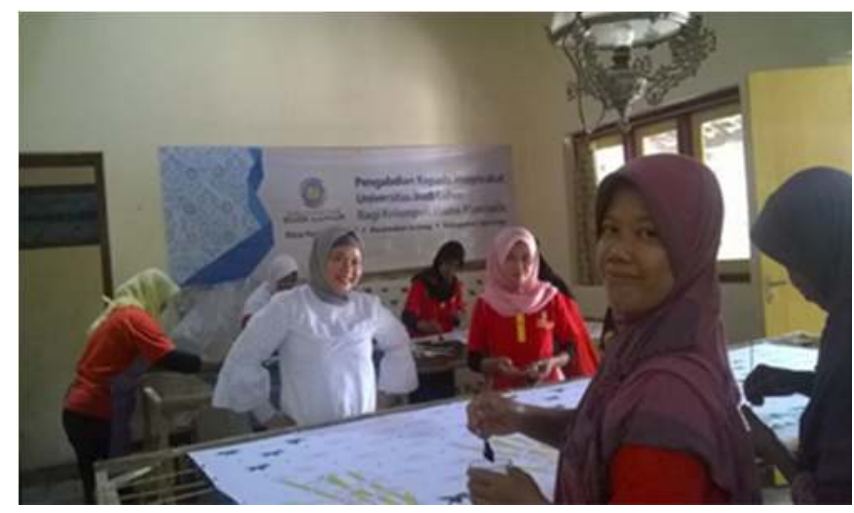

Figure 2. Batik Activity

\section{RESULT AND DISCUSSION}

\section{Result Outcomes Socialization}

In order to follow up the program work plan in terms of the realization of changes the way of conventional marketing. We visited the field at Kedung Kamal village at Purworejo.Activities are comprising with :

1. Observation

Observation begin at odd semester 2017/2018. Based on the observation has gain information about obstacles encountered by member of Batik Arimbi's in Kedung Kamal village, Grabag at Purworejo. The activity about the low point of promotion until lack of interest people at Purworejo to buy local batik.After brainstorming with Batik Arimbi's organizer. The team decided to give training about e-commerce for Batik Arimbi group of crafts.

2. Presentation, accompaniment and evaluation

The method that implemented on community development arepresentation, accompaniment and evaluation.

\section{Preparation}

Contacting via correspondence by Budi Luhur team to organizer from Batik 'ARIMBI' at Kedung Kamal Village, GrabagPurworejo. The correspondence was arranged the venue and timing for conducting training as well as accompaniment.

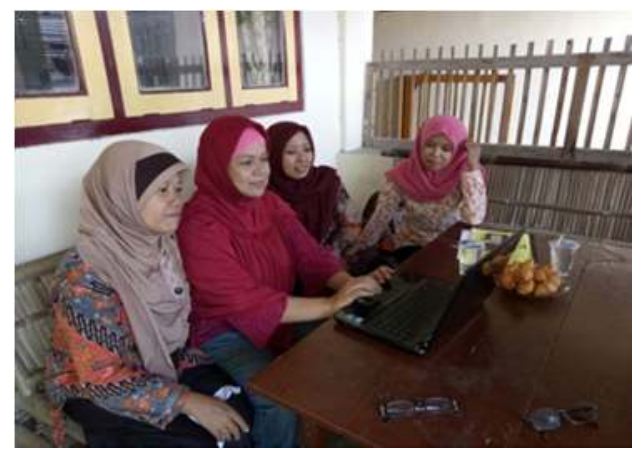

Figure 3: Introducing E-Commerce for Batik Organizer

\section{Execution}


The team was held a presentation about the marketing strategy and using online media forparticipant were allowed to ask the questions to speaker. During the question and answer participant able to reveal the obstacles of using internet or conventional marketing. The second presentation were about create account on e-commerce and tried to signed to join e-commerce.

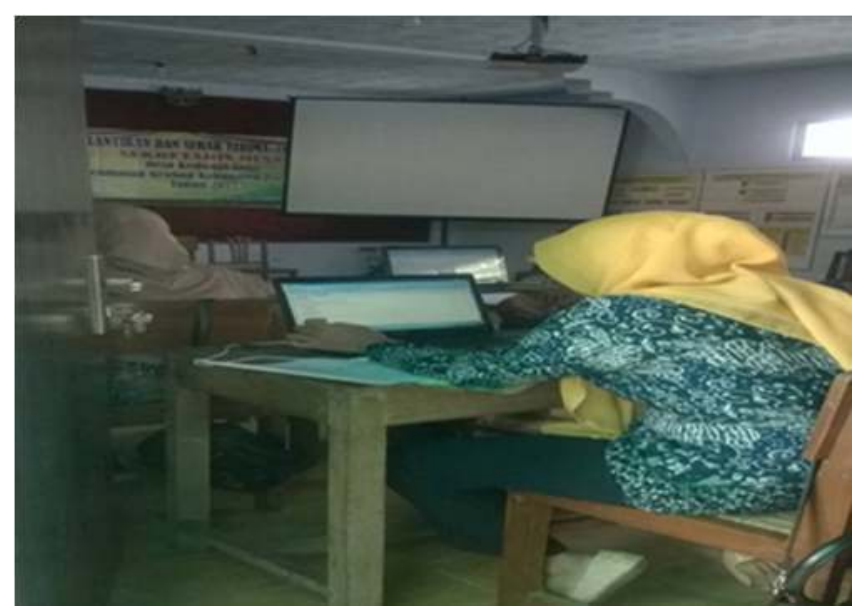

Figure 4. Training Computer for Batik Craftswomen

\section{Discussion}

1. Training Of Using E-Commerce As Marketing Tools.

Introducing Batik Purworejo produced by Batik Arimbi. Marketing product of Arimbi batik has done with conventional way like batik product by entrusted with small shop from one of member of group of entrepreneur. Local government of Purworejo district has invited group of Arimbi batik entrepreneur to be a participant on local exhibition. The exhibition held to embrace government official or other celebration. Problem is occurred because the product has not sold yet and lend by organizer and unable to be returned. It is expected that the training from Universitas Budi Luhur can be solved those problem. The training is about giving counseling to the group of Arimbi Batik entrepreneur by using digital marketing such as: media social or e-commerce.

2. Training Of Computer For House Wife From Batik Arimbi'sOrganisation

During the training program, the organizer of the group of entrepreneur has successfully using and joining computer training held by local government through Kedung Kamal village office, in Purworejo.The material has gained are Ms word and Ms excel. After joining the training the organizer of group of Arimbi batik entrepreneurs directed to use information and technology on marketing activities. Participant are given with the examples of future marketing. As well as the organizer of Batik Arimbi group entrepreneurs facilitated with tools or application for e-commerce as sustainability of this training.

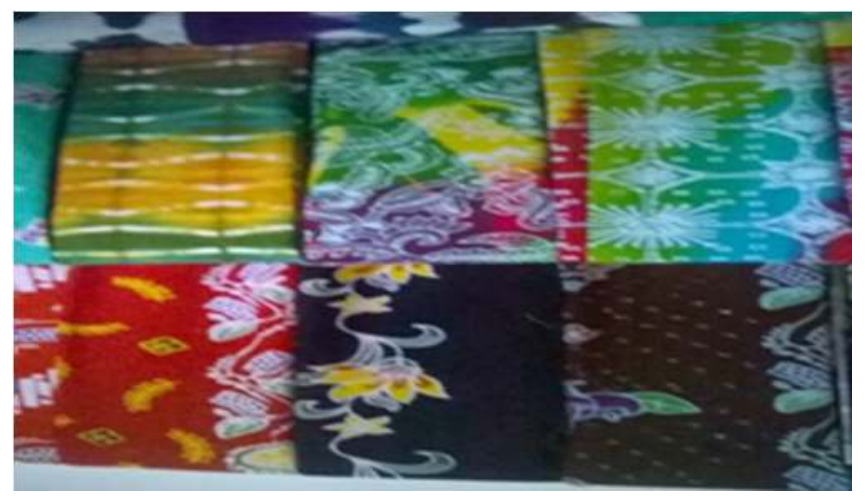

Figure 5: Batik production from Batik's Arimbi 


\section{CONCLUSION}

\section{Conclusion}

Marketing product of Batik 'ARIMBI' at Kedung Kamal village, Grabag, Purworejo can be developed by using digital marketing instead of conventional marketing by selling at the local store. Using digital marketing can be joined with e-commerce such as; Tokopedia, Bukalapak or Shoppee. There are many of e-commerce that assist Batik 'ARIMBI' to sell their batik. As well as introduce local Purworejo Batik.On the other hand Batik ARIMBI's organizer has joined with many trainings particularly about entrepreneurship and computer operation. Those skill can be transferred to the member of Batik "ARIMBI" in order to enhance knowledge of marketing digital. At the last successfully operation marketing digital is able to raise the domestic income.

\section{Suggestion}

Based on the discussion result from craftswomen and observed during training. So, it can suggested as below:

1. Local government needs to give extended computer training, those are optimize e-commerce from digital marketing technology to market the local product like Batik. In this case local government can work together with academician to conduct the mentoring and training program.

2. Head of group Batik ARIMBI that given training about marketing including digital marketing using e-commerce, as well as entrepreneurship. It is expected to those had training able to delivered to other member. So, that it can be implemented immediately.

\section{REFERENCES}

Madcom.(2011). Sukses Membangun Toko Online dengan E-Comerce. Andi Publisher. Yogyakarta.

Lupiyoadi, R. (2007), Entrepreneurship: From mindset to strategy, Lembaga Penerbit Fakultas Ekonomi Universitas Indonesia. Jakarta.

Suryana. (2006). Kewirausahaan Pedoman Praktis: Kiat dan Proses Menuju Sukses, Salemba Empat. Jakarta.

Winardi. (2003). Entrepreneur \& Entrepreneurship, Kencana, Jakarta. 